\title{
Attitude of accepting dental implant treatment among aged patients
}

\author{
Claudia Florina Andreescu* \\ Department of Prosthetics, Faculty of Dental Medicine, University Titu Maiorescu, Bucharest, Romania
}

\begin{abstract}
Number of elderly people is increasing worldwide in the same time with an increasing demand of dental implants to replace missing teeth. Treatment plan for mature patient is more complex and implies biological, clinical and socio-economic criteria. Although, there is a trend in use of implants in aged patients, treatment plan should deal with issues of patients will face with the advancing age: chronic diseases, difficulties in cleaning teeth, decreased income.
\end{abstract}

Number of elderly people, senior citizens, is growing worldwide, as demographic developments indicate. There is an increasing life expectancy of the individual and the aging process of modern society is going to maintain with economic, cultural and medical consequences, this age group being the main consumer of health services.

Use of dental implants to replace missing teeth becomes more and more popular due to good chewing efficiency and preservation of natural teeth. With careful diagnosis and treatment planning, aged patients are good candidates for dental implants when the treatment plan is accurate [1]. Results from a recent study [2] indicate that patients with advanced age, in reasonably good health, have excellent implant survival rates, excellent quality of life scores, and can be maintained in good oral health.

Dental care of elderly persons is similar to dental care of younger persons, but is modified by age-associated changes, chronic diseases and medications. Therefore, therapists should be familiar with the physiology of ageing and the management of problems associated with the care of the older adult and with the presentation of oral and dental diseases and chronic diseases in the older adult [3].

As a result, clinical decision-making for the dental treatment plan of elderly patients is more complex. Biological, clinical and socioeconomic criteria are taken in consideration when planning the treatment. Age itself is not a contraindication for implant placement [4], but dental implants can be placed successfully in the elderly with good clinical and socio-economic outcomes [5]. Although, implantborne prostheses have established benefits over traditional alternatives, age-related changes in systemic and oral health in association with social, economic and factors complicate dental implant treatment of ageing patients. When time, opportunity, discomfort and maintenance costs are coupled with cost-benefit and quality of life predictions, otherwise simple treatment decisions can become more difficult [6].

Two- or even one-implant overdenture for the edentulous mandible is regarded as a minimum standard of care in many developed countries $[7,8]$ and implant-supported denture is the appropriate treatment of mature patients becoming edentulous [9]. There is sufficient evidence to affirm that the mandibular implant overdenture is a well-established treatment modality, in nondependent edentulous individuals [10], but indication of implant-supported dentures is questionable for patients who have become dependent on others for daily oral health care. Dependent elderly people can benefit from oral implants, when adequate aftercare can be provided [11].

Despite the convincing data about dental implant, a great number of aged patients refuse implant placement. Walton and MacEntee [12] reported a $35 \%$ refusal rate when recruiting for a study where two implants would be placed to retain a lower denture, all at no cost to the patient. The most common reason for refusal implant therapy, even when cost of treatment, consider as limiting factor, is eliminated, was concern about surgical risks.

Ellis et al [13] investigated refusal of implant supported mandibular overdentures by elderly patients and two main themes emerged: patients' fear and anxiety related to surgery, and the appropriateness of the procedure in an elderly person.

A more recent study [14] described as the strongest apprehensions against implants: cost, lack of perceived necessity and old age.

The most commonly cited reason for declining implant treatment is the high cost and old age [15]. Other reasons for declining implant treatment are: elderly patients are satisfied with their dentures, or they have more important priorities in their lives, especially when they suffer from multiple chronic diseases. In addition, the patient's age and degenerative diseases may make the stress of surgery and long dental appointments undesirable.

Attitude toward desire for implant treatment has change with time; Narby et al [16] describe a dramatic increase in the interest for

Correspondence to: Claudia Florina Andreescu, DDS, PhD, Associate Professor, Faculty of Dental Medicine, University Titu Maiorescu, Bucharest, 67A Gheorghe Petrascu Street, sector 3, Bucharest, code 031593, Romania, Email: claudia_andreescu@yahoo.com

Key words: ageing, dental implants, attitude to treatment

Received: October 02, 2017; Accepted: October 25, 2017; Published: October 28,2017 
implant treatment over the period from 1989 to 1999 among middleaged and older Swedish subjects. Older people, non-city residents, and those with one or few missing changed their desire for implant therapy and main factors influencing desire are: income and dental status [17]. Since people expect to retain their teeth for longer, they are prepared to invest time, money, and energy in the maintenance and restoration of existing dentition [18].

In recent years, the use of implants in aged patients requiring prostheses has been increasing. However, it remains an expensive therapy, which involves surgical trauma to the tissues. Widespread use of this approach in mature patients raises questions from both the clinical and ethical points of view. There are some questions that should answer:

\section{What treatment options exist?}

2. What patient wants?

3. What implies aftercare?

4. Which is the maintenance cost and possibilities to repair or replace?

5. What is the financial impact of each option?

6. Does the patient and/or their family understand all the considerations?

The treatment plan of aged patient should deal with issues of patients will face with the advancing age: chronic diseases, difficulties in cleaning teeth, decreased income.

\section{References}

1. Stanford CM (2007) Dental implants. A role in geriatric dentistry for the genera practice? J Am Dent Assoc 138 Suppl: 34S-40S. [Crossref]

2. Becker W, Hujoel P, Becker BE, Wohrle P. (2016) Dental implants in an aged population: evaluation of periodontal health, bone loss, implant survival, and quality of life. Clin Implant Dent Relat Res 18: 473-479. [Crossref]

3. Hellyer PH (2011) The older dental patient - who cares? Br Dent J 211: 109-111. [Crossref]
4. Sendyk DI, Rovai ES, Pannuti CM, Deboni MCZ, Sendyk WR, et al. (2017) Dental implant loss in older versus younger patients: a systematic review and meta-analysis of prospective studies. J Oral Rehabi 44:229-236. [Crossref]

5. Bartold PM, Ivanovski S, Darby I (2016) Implants for the aged patient: biological, clinical and sociological considerations. Periodontol 2000 72: 120-134. [Crossref]

6. Dudley J1 (2015) Implants for the ageing population. Aust Dent $J 60$ Suppl 1: 28-43. [Crossref]

7. Carlsson GE1, Omar R (2010) The future of complete dentures in oral rehabilitation. A critical review. J Oral Rehabil 37: 143-156. [Crossref]

8. de Baat C1 (2000) Success of dental implants in elderly people--a literature review Gerodontology 17: 45-48. [Crossref]

9. Carlsson GE (2014) Implant and root supported overdentures - a literature review and some data on bone loss in edentulous jaws. J Adv Prosthodont 6: 245-252. [Crossref]

10. Thomason JM, Feine J, Exley C, Moynihan P, Müller F, et al. (2009) Mandibular two implant-supported overdentures as the first choice standard of care for edentulous patients--the York Consensus Statement. Br Dent J 207: 185-186. [Crossref]

11. Visser A, de Baat C, Hoeksema AR, Vissink A (2011) Oral implants in dependent elderly persons: blessing or burden? Gerodontology 28: 76-80. [Crossref]

12. Walton JN, MacEntee MI (2005) Choosing or refusing oral implants: a prospective study of edentulous volunteers for a clinical trial. Int J Prosthodont 18: 483-488. [Crossref]

13. Ellis JS, Levine A, Bedos C, Mojon P, Rosberger Z, et al. (2011) Refusal of implant supported mandibular overdentures by elderly patients. Gerodontology 28(1):62-68. [Crossref]

14. Müller F, Salem K, Barbezat C, Herrmann FR, Schimmel M. (2012) Knowledge and attitude of elderly persons towards dental implants. Gerodontology 29:e914-e923. [Crossref]

15. Merz MA, Terheyden H, Huber CG, Seixas AA, Schoetzau A, et al. (2017) Facilitators and barriers influencing the readiness to receive dental implants in a geriatric institutionalised population-A randomized non-invasive interventional study. Gerodontology 34:306-312. [Crossref]

16. Narby B, Kronström M, Söderfeldt B, Palmqvist S (2008) Changes in attitudes toward desire for implant treatment: a longitudinal study of a middle-aged and older Swedish population. Int J Prosthodont 21: 481-485. [Crossref]

17. Narby B, Bagewitz IC, Söderfeldt B. (2011) Factors explaining desire for dental implant therapy: analysis of the results from a longitudinal study. Int J Prosthodont 24(5):437-444. [Crossref]

18. Shanahan D, O’Neill D. (2016) Dental implants and older patients-Knowing the drill. European Geriatric Medicine 7:504-505.

Copyright: (C2017 Andreescu CF. This is an open-access article distributed under the terms of the Creative Commons Attribution License, which permits unrestricted use, distribution, and reproduction in any medium, provided the original author and source are credited. 